\title{
Inactivation of Escherichia coli O157:H7 by High Hydrostatic Pressure Combined with Gas Packaging
}

\author{
Bing Zhou 1,2,3,4, Luyao Zhang ${ }^{1,2,3,4}$, Xiao Wang ${ }^{1,2,3,4}$, Peng Dong 1,2,3,4 Xiaosong Hu $1,2,3,4$ and \\ Yan Zhang 1,2,3,4,* \\ 1 College of Food Science and Nutritional Engineering, China Agricultural University, Beijing 100083, China; \\ bingcau110@163.com (B.Z.); zhangly7667@163.com (L.Z.); echowang2014@163.com (X.W.); \\ dongpeng12@hotmail.com (P.D.); huxiaos@263.net (X.H.) \\ 2 National Engineering Research Center for Fruits and Vegetables Processing, Ministry of Science and \\ Technology, Beijing 100083, China \\ 3 Key Laboratory of Fruits and Vegetables Processing, Ministry of Agriculture and Rural Affairs, \\ Beijing 100083, China \\ 4 Beijing Key Laboratory of Food Non-Thermal Processing, Beijing 100083, China \\ * Correspondence: zhangyan348@163.com; Tel.: +86-10-62737434-23
}

Received: 19 April 2019; Accepted: 16 May 2019; Published: 28 May 2019

\begin{abstract}
The inactivation of Escherichia coli O157:H7 (E. coli) in physiological saline and lotus roots by high hydrostatic pressure (HHP) in combination with $\mathrm{CO}_{2}$ or $\mathrm{N}_{2}$ was studied. Changes in the morphology, cellular structure, and membrane permeability of the cells in physiological saline after treatments were investigated using scanning electron microscopy, transmission electron microscopy, and flow cytometry, respectively. It was shown that after $\mathrm{HHP}$ treatments at $150-550 \mathrm{MPa}, \mathrm{CO}_{2}$-packed E. coli cells had higher inactivation than the $\mathrm{N}_{2}$-packed and vacuum-packed cells, and no significant difference was observed in the latter two groups. Further, both the morphology and intracellular structure of $\mathrm{CO}_{2}$-packed E.coli cells were strongly destroyed by high hydrostatic pressure. However, serious damage to the intracellular structures occurred in only the $\mathrm{N}_{2}$-packed E. coli cells. During $\mathrm{HHP}$ treatments, the presence of $\mathrm{CO}_{2}$ caused more disruptions in the membrane of $E$. coli cells than in the $\mathrm{N}_{2}$-packed and vacuum-packed cells. These results indicate that the combined treatment of $\mathrm{HHP}$ and $\mathrm{CO}_{2}$ had a strong synergistic bactericidal effect, whereas $\mathrm{N}_{2}$ did not have synergistic effects with HHP. Although these two combined treatments had different effects on the inactivation of E. coli cells, the inactivation mechanisms might be similar. During both treatments, E. coli cells were inactivated by cell damage induced to the cellular structure through the membrane components and the extracellular morphology, unlike the independent HHP treatment.
\end{abstract}

Keywords: high hydrostatic pressure; carbon dioxide; nitrogen; modified atmosphere packaging; Escherichia coli

\section{Introduction}

During the last decade, some mild and efficient food preservation technologies have been developed to satisfy the growing consumer demands for minimally processed and preservative-free food products [1]. Among these technologies, high hydrostatic pressure (HHP) processing technology is a new, commercially successful nonthermal technology that meets these consumer demands to some extent while retaining the sensorial and nutritional properties of freshly prepared foods [2]. Compared with conventional technologies, HHP can inactivate food spoilage and pathogenic microorganisms at room temperature, extend the shelf life of foods, and reduce damage to heat-sensitive food components and the formation of harmful food components such as heterocyclic amines (HCAs) caused by high temperature [3-5]. In addition, unlike thermal processing and other preservations, pressure can 
penetrate the entire food product to inactivate both surface and internalized microorganisms and acts instantaneously and uniformly throughout foods regardless of size, shape, and geometry [6,7].

However, two main deficiencies of HHP treatment exist that limit its commercial use in low-acid foods. One is the economic costs of the high-pressure equipment that can reach pressures up to $600 \mathrm{MPa}$ or more, which are required to efficiently inactivate microorganisms in food [8]. The other is its weak inactivation of bacterial spores, the most resistant cell type known. At room temperature, high-pressure food processes have been reported to be effective in reducing or inactivating vegetative pathogens, human rotavirus, hepatitis A virus, and calicivirus in foods [5], but even ultra-high pressure levels (1000 MPa) are not effective at inactivating bacterial endospores [9]. In order to overcome these critical drawbacks of HHP, various preservative factors (hurdles) to increase or accompany the efficacy of pressure-induced inactivation of microorganisms have been thoroughly studied, including moderate temperature, $\mathrm{pH}$, modified atmospheres, other nonthermal food processing methods, and antimicrobial agents such as nisin [10-13].

The combination of HHP and modified atmosphere packaging (MAP) as an effective synergistic treatment that has attracted much attention [14]. Modified atmosphere packaging (MAP) is a well-established technology that is generally used for extending the shelf-life of minimally processed foods by replacing the surrounding atmosphere of the food with a gas mixture. The gas mixture usually includes the bactericidal gas $\mathrm{CO}_{2}$ and the comparatively inert gases of $\mathrm{N}_{2}$ and $\mathrm{O}_{2}$. It is reported that microbial growt could be inhibited by compressed gas $\left(\mathrm{CO}_{2}, \mathrm{Kr}, \mathrm{Xe}\right.$, and $\left.\mathrm{N}_{2} \mathrm{O}\right)$ over a range of pressures $(1.5$ to $5.5 \mathrm{MPa})[15,16]$. Also, combining modified atmosphere packaging $\left(50 \% \mathrm{O}_{2}+50 \% \mathrm{CO}_{2}\right)$ with low high pressure (150 MPa) was investigated for shelf-life extension of carrots, and it was found that spoilage microorganisms and pathogens are more susceptible to being inactivated by HHP in the presence of gas [17]. Furthermore, due to the bacteriostatic effect of $\mathrm{CO}_{2}$, pressurized $\mathrm{CO}_{2}$, known as high-pressure carbon dioxide (HPCD), whose pressure level is less than $100 \mathrm{MPa}$, has been widely used to inactivate microorganisms in foods and has become an alternative nonthermal pasteurization technique for foods [18].

In recent years, the synergistic effect of antimicrobial gas $\left(\mathrm{CO}_{2}\right)$ and $\mathrm{HHP}$, in which the pressure level is more than $100 \mathrm{MPa}$, has been extensively reported in the literature [19-21]. The inactivation effect of HHP on bacteria was greatly enhanced by using a new setup to dissolve and retain the concentration of $\mathrm{CO}_{2}$ in fruit juices [22]. Further, low- or medium-acid fruit and vegetable juices treated with a combination of $\mathrm{HHP}$ and dissolved $\mathrm{CO}_{2}$ were also effectively preserved. More importantly, when using $\mathrm{CO}_{2}$ in combination with $\mathrm{HHP}$, the treatment pressure could be reduced without compromising a reduction in microbial count.

However, how this treatment synergistically inactivates the valid objective microorganisms is unexplored. Furthermore, the mechanism of this synergic effect remains elusive. Thus, we determined the effect of high nitrogen $\left(\mathrm{N}_{2}\right)$ and high carbon dioxide $\left(\mathrm{CO}_{2}\right)$ on the inactivation effect of high pressure on Escherichia coli O157:H7. We investigated the morphology and cellular structures by scanning electron microscopy (SEM), transmission electron microscopy (TEM), and flow cytometry (FCM) to provide more evidence for the microbial inactivation mechanism of HHP treatment combined with gas.

\section{Materials and Methods}

\subsection{Bacterial Strain and Culture Conditions}

A stock culture of E. coli (CGMCC1.90), obtained from the China General Microbiological Culture Collection Center (CGMCC, Beijing, China), was maintained on nutrient agar (NA) plates (Beijing Aoboxing Biological Technology, Beijing, China). The E. coli inoculum was made by transferring a single colony to $20 \mathrm{~mL}$ of nutrient broth (NB, Beijing Aoboxing Biological Technology, Beijing, China), which was shaken at $170 \mathrm{rpm}$ at $37^{\circ} \mathrm{C}$ for $12 \mathrm{~h}$ to obtain cells in stationary phase. Cultures were inoculated by transferring a $1 \%(\mathrm{v} / \mathrm{v})$ inoculum to $1.5 \mathrm{~L}$ nutrient broth and continuing growth under the same conditions as described above for $2.5 \mathrm{~h}$ to obtain cells in the middle exponential phase. Cells 
were harvested, washed twice in sterile physiological saline (PS, 0.85\% NaCl solution, pH 6.80) and resuspended in PS. For some samples, E. coli cells were resuspended in sterilized lotus root sauce. Sterilized lotus root sauce was prepared by the following procedure. At first, the lotus root was homogenized by the beating machine. Then, the acquired sauce was autoclaved at $121{ }^{\circ} \mathrm{C}$. The final number of $E$. coli cells generally ranged from $10^{7}$ to $10^{8}$ CFU per milliliter (mL).

\subsection{Packing and HHP Processing}

A $50 \mathrm{~mL}$ E. coli cell suspension was transferred to ultraviolet-sterilized polyethylene terephthalate (PET) trays $(200 \mathrm{~mL})$ and then conditioned under $100 \% \mathrm{CO}_{2}$ or $100 \% \mathrm{~N}_{2}$ using a DT-6A modified atmosphere packaging machine (Dajiang machinery equipment CO., Ltd., Zhejiang, China). The other cell suspensions were transferred to sterile polyethylene plastic bags, vacuum packed, and stored at $4{ }^{\circ} \mathrm{C}$ for less than $1 \mathrm{~h}$ before treatment.

These samples were treated in a hydrostatic pressurization unit (HHP-750, Baotou Kefa Co., Ltd., Inner Mongolia, China) with a chamber of $30 \mathrm{~L}$ capacity. The pressure-transmitting fluid was water. The treatment time in this study did not include the pressurization and depressurization times. The prepared samples were placed in the pressure vessel and treated at 150, 250, 350, 450, and $550 \mathrm{MPa}$ for $1 \mathrm{~min}$ at room temperature.

\subsection{Determination of Viable Cells}

Treated and untreated samples were serially diluted and surface plated on NA agar plates (Oxoid, Basingstoke, UK). Plates were incubated at $37^{\circ} \mathrm{C}$ for $24 \mathrm{~h}$, and then the colonies were enumerated. Survival was expressed as the logarithmic viability reduction $\log 10\left(\mathrm{~N}_{\mathrm{i}} / \mathrm{N}_{0}\right)$ with $\mathrm{N}_{0}$ and $\mathrm{N}_{\mathrm{i}}$ representing the colony counts before and after HHP treatment, respectively. Survival counts are presented as averages \pm standard deviation of three independent experiments.

\subsection{SEM and TEM Analysis}

According to previous methods [23,24], a suspension of E. coli cells was centrifuged at $8000 \times \mathrm{rpm}$ for $10 \mathrm{~min}$ at $4{ }^{\circ} \mathrm{C}$, the supernatant was removed, and then the pellet was resuspended in $2.5 \%(\mathrm{v} / \mathrm{v})$ glutaraldehyde solution to fix for $12 \mathrm{~h}$. After fixation, the cells in suspension were washed several times with $0.1 \mathrm{M}$ phosphate buffer (PBS, pH 7.2) and fixed again by $1 \%$ osmium tetroxide solution ( $\mathrm{pH}$ 7.2). After $1.5 \mathrm{~h}$, the cells were washed in PBS three times and dehydrated $10 \mathrm{~min}$ each with a series of cold ethanol solutions $(10 \%, 30 \%, 50 \%, 75 \%$, and $95 \%)$. For the SEM assay, the dehydrated cells were rinsed with 50\%,70\%, 90\%, and 100\% isoamyl acetate for 3 min each, critical point dried, and coated with gold-palladium for $60 \mathrm{~s}$. Observations and photomicrographs were carried out with a Hitachi S-3400 N SEM (Hitachi Instruments Inc., Tokyo, Japan) and a JEM-1230 TEM (JEOL Japan Electronics Co., Ltd., Japan).

\subsection{FCM Analysis}

The FCM analysis of untreated cells (negative control), 75\% isopropanol-treated cells (positive control), and the above-treated cells were measured as described by previous studies $[23,25]$. Cell suspensions were washed twice with physiological saline, resuspended in physiological saline, and adjusted to $10^{8}-10^{9} \mathrm{CFU} / \mathrm{mL}$. Then, $0.15 \mu \mathrm{L}$ of dye mixture containing equivalent SYTO9 (Sigma-Aldrich, St. Louis, MO, USA) and propidium iodine (PI, Sigma-Aldrich, USA) were added to $50 \mu \mathrm{L}$ of the cell suspensions and incubated for $20 \mathrm{~min}$ at room temperature in the dark. After that, the cells were immediately analyzed with a BD FACSCalibur flow cytometer (BD Biosciences, San Jose, CA, USA) and about 30,000 cells were collected in each run. Forward scatter and side scatter were collected, and the fluorescence signals were collected in the FL1 (green fluorescence of SYTO9 at 502 nm) and FL2 (red fluorescence of PI at $613 \mathrm{~nm}$ ) channels [26] using Cell Quest software (Becton Dickinson, San Jose, CA, USA). 


\subsection{Statistical Analysis}

All experiments were repeated at least three times. All data were statistically analyzed using Microcal Origin 8.1 (Microcal Software, Inc., Northampton, MA, USA).

\section{Results and Discussion}

\subsection{Inactivation of E. coli in Buffer and Lotus Root Suspension}

The inactivation of vacuum-packed, $\mathrm{N}_{2}$-packed, and $\mathrm{CO}_{2}$-packed E. coli cells subjected to high pressure at 150-550 MPa at room temperature for $1 \mathrm{~min}$ is shown in Figure 1a. When the pressure was at $150 \mathrm{MPa}$, there was no significant difference in inactivation levels among these cells, as indicated by less than 2 logs of inactivation for them (Figure 1a). This indicated that the synergistic effect of low high pressure and gas on the inactivation of $E$. coli cells did not occur. However, the reduction in cell counts of $\mathrm{CO}_{2}$-packed E. coli cells was about 1, 4, and 2 logs more than that of vacuum-packed and $\mathrm{N}_{2}$-packed cells at $250 \mathrm{MPa}, 350 \mathrm{MPa}$, and $450 \mathrm{MPa}$, respectively (Figure 1a). Furthermore, a reduction of more than $8 \log$ units, the detection limit, was achieved at $350 \mathrm{MPa}$ for $\mathrm{CO}_{2}$-packed cells; the pressure for a similar inactivation effect for vacuum-packed and $\mathrm{N}_{2}$-packed cells was $550 \mathrm{MPa}$ (Figure 1a). Thus, we conclude that the combined treatment of moderately high pressure (250-450 MPa) and $\mathrm{CO}_{2}$ showed a strong synergistic bactericidal effect.

Next, we sought to determine whether the similar inactivation kinetics of HHP combined with gases also exist in E. coli cells suspended in lotus root. Comparing the results in Figure 1a,b, the inactivation levels of samples with three packages were 1 to 3 logs in lotus root less than in buffer at $150 \mathrm{MPa}$ to $450 \mathrm{MPa}$. This observation that inactivation of $E$. coli by different treatments was more extensive in the buffer than in the lotus root under all conditions may be because a complex matrix has a protective effect on bacterial inactivation compared with a buffer system $[27,28]$. However, the reduction of $\mathrm{CO}_{2}$-packed $E$. coli in lotus root was also more than in vacuum-packed and $\mathrm{N}_{2}$-packed cells at $250 \mathrm{MPa}, 350 \mathrm{MPa}$, and $450 \mathrm{MPa}$ (Figure 1b).

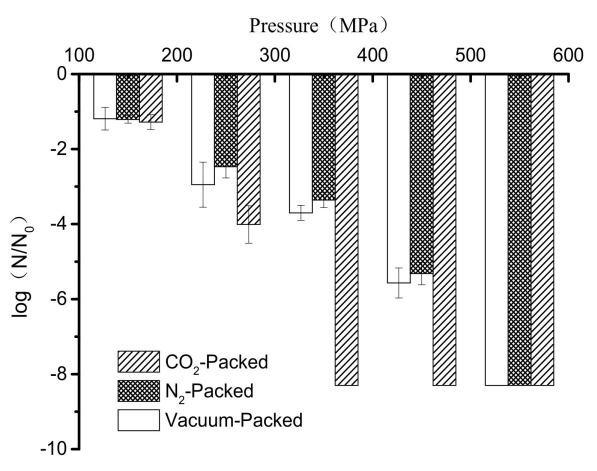

(a)

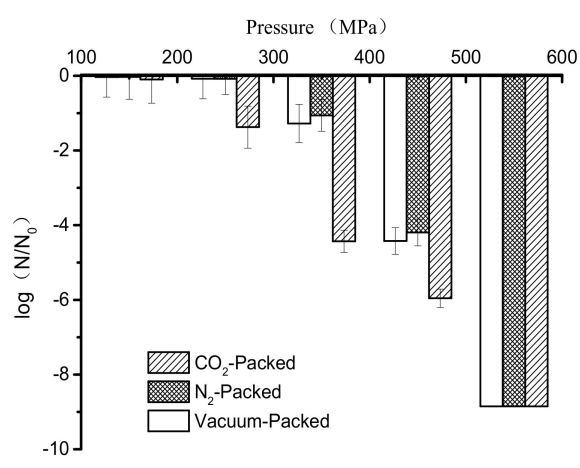

(b)

Figure 1. Inactivation of differently packed E. coli cells suspended in physiological saline by treatment with different pressures (a); Inactivation of differently packed E. coli suspended in lotus roots pulps by treatment with different pressures $(\mathbf{b})$.

It was reported that the combined treatment with $\mathrm{HHP}$ and dissolved $\mathrm{CO}_{2}$ effectively preserved the low- or medium-acid fruit and vegetable juices compared with HHP treatment [21]. Further, a synergistic effect of the combination of $\mathrm{HHP}$ and $\mathrm{CO}_{2}$ against microorganisms inoculated in poultry sausages was found [20]. This synergistic effect may be due to the increased penetration of $\mathrm{CO}_{2}$ into the microorganism cells under high pressure. Therefore, we can conclude that the combined application of high pressure and different gases would have different effects on inactivating E. coli. The presence of $\mathrm{CO}_{2}$ could significantly enhance the inactivation of $E$. coli treated with high pressure, which was obvious at a moderately high pressure. Nevertheless, the presence of $\mathrm{N}_{2}$ did not affect the inactivation at high pressure. 
3.2. The Morphology and Intracellular Structure Changes of E. coli Cells Treated with High Pressure Combined with Gas

From the above results, the inactivation of $E$. coli cells by high pressure was indeed affected by gases, which is obvious at 250, $350 \mathrm{MPa}$, and $450 \mathrm{MPa}$ (Figure 1). Therefore, we used scanning electron microscopy to examine changes in the morphology of $\mathrm{CO}_{2}$-packed, $\mathrm{N}_{2}$-packed, and vacuum-packed E. coli cells in buffer exposed to these pressures. The untreated E. coli cells showed a morphology with a regular rod shape and smooth surface (Figure 2a). After high-pressure treatment at $250 \mathrm{MPa}$ or $350 \mathrm{MPa}$, both the vacuumand $\mathrm{N}_{2}$-packed E. coli cells had a similar morphology to the untreated samples (Figure 2b,d,e,g); however, the $\mathrm{CO}_{2}$-packed cells were collapsed and exhibited holes and wrinkles on the surface (Figure 2c). When the treating pressure increased to $450 \mathrm{MPa}, \mathrm{N}_{2}$-packed E. coli cells were still intact and exhibited similar morphology to that at $250 \mathrm{MPa}$ and $350 \mathrm{MPa}$ (Figure $2 \mathrm{~d}, \mathrm{~g}, \mathrm{j}$ ), while a portion of the vacuum-packed E. coli cells was broken and showed cellular debris. Of note, the morphology of $\mathrm{CO}_{2}$-packed E. coli suspensions was further damaged as shown by noticeable hollows, wrinkles, or holes on their surface, and the cellular debris that was caused by cell breakdown (Figure 2f,i).

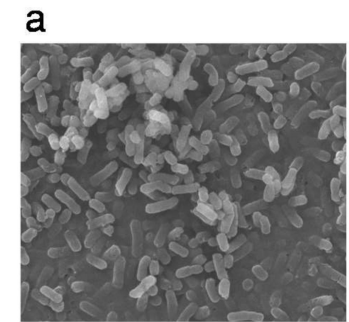

b

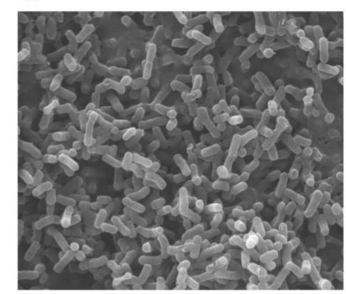

e

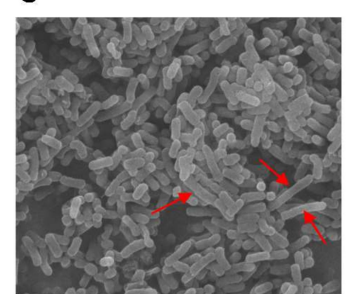

$\mathrm{h}$

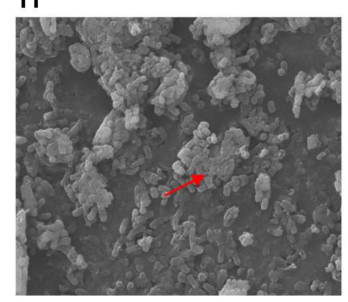

C

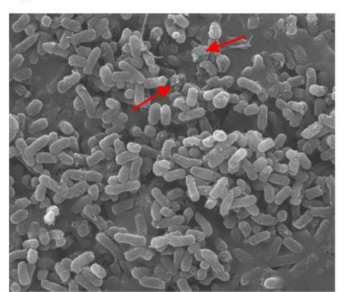

f

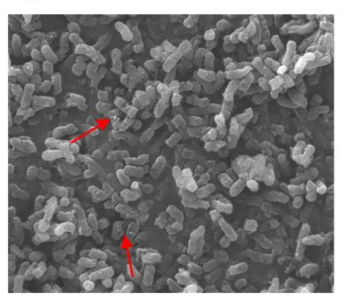

i

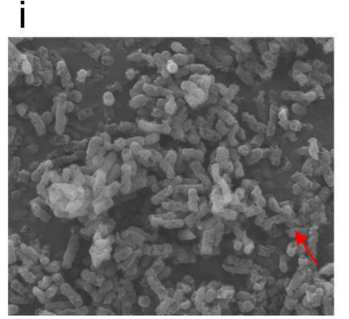

d

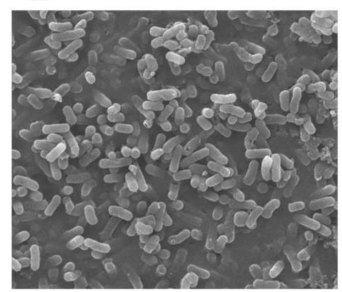

g
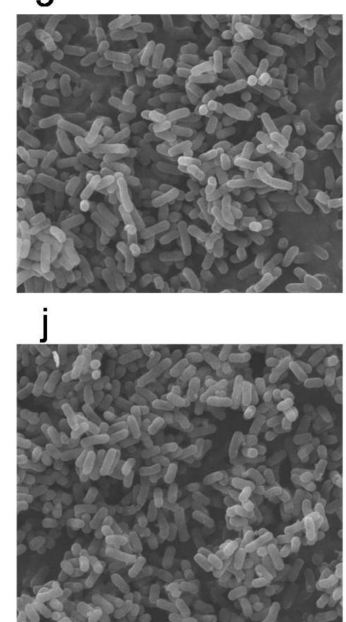

Figure 2. The scanning electron microscopy (SEM) images of differently packed E. coli before and after different pressure treatments. Untreated E. coli cells (a); vacuum-packed (b), $\mathrm{CO}_{2}$-packed (c), and $\mathrm{N}_{2}$-packed (d) E. coli cells after high hydrostatic pressure (HHP) treatment at $250 \mathrm{MPa}$ : Vacuum-packed (e), $\mathrm{CO}_{2}$-packed (f) and $\mathrm{N}_{2}$-packed (g) E. coli cells after HHP treatment at $350 \mathrm{MPa}$; Vacuum-packed (h), $\mathrm{CO}_{2}$-packed (i) and $\mathrm{N}_{2}$-packed (j) E. coli cells after HHP treatment at $450 \mathrm{MPa}$. Red arrows represent the remarkable phenotypes. 
As shown in the above results, while $\mathrm{N}_{2}$-packed $E$. coli cells were seriously inactivated by different pressure treatments ( 2 to $5 \log$ units), their morphology remained stable (Figures 1 and $2 \mathrm{~d}, \mathrm{~g}, \mathrm{j})$. This apparent contradiction may be because $\mathrm{N}_{2}$ is an inert gas and does not dissolve in the water phase, which can induce two phases at high pressure-a water phase and a gas phase [29]. Therefore, destruction of the morphology induced by HHP processing may be decreased in this complex two-phase system. In addition, compressed $\mathrm{N}_{2}$ may penetrate the cell to balance between the internal and external environment, which has an additional protective effect on morphology.

The effects of HHP treatment combined with gas on the intracellular structure of E. coli cells were assessed by transmission electron microscopy. The exposure of vacuum-packed cells to pressures ranging from $250 \mathrm{MPa}$ to $450 \mathrm{MPa}$ induced a slight increase in transparency within the nucleoid areas and the presence of aggregated proteins (Figure $3 b, e, h$ ). Although $\mathrm{N}_{2}$-packed cells showed similar changes in cellular structure to the vacuum-packed cells at $250 \mathrm{MPa}$ (Figure 3b,d), the intracellular damage exhibited by $\mathrm{N}_{2}$-packed cells was more noticeable than with the vacuum-packed cells at 350 and $450 \mathrm{MPa}$. This was evidenced by the apparent disorganization of the genome area, the appearance of blank space in the cytoplasm and the condensation of the cytoplasmic material, and the serious intensity and frequency of protein aggregation within the cell cytoplasm (Figure 3g,j). However, the membranes of the $\mathrm{N}_{2}$-packed cells were organized, whereas the membranes of the vacuum-packed cells displayed winding shapes, and some of them were disrupted or detached from the cytoplasmic content (Figure $3 b, d, e, g, h, j)$. Remarkably, the $\mathrm{CO}_{2}$-packed cells showed the most damage of the intracellular structures from high-pressure treatment (Figure 3c,f,i). When the treatment pressure increased, the distribution of the amorphous structures became uneven and the genome area was disorganized. Also, there were large clumps of aggregated protein in the cells. The intensity of the damage of the intracellular structures and the weak wrinkling membranes of the $\mathrm{CO}_{2}$-packed cells increased (Figure 3c,f,i).

Taken together, both the morphology and intracellular structure of $\mathrm{CO}_{2}$-packed E. coli cells were more strongly destroyed by high pressure. Known as the most important gas in $\mathrm{MAP}, \mathrm{CO}_{2}$ can dissolve in the water phase to form carbonic acid $\left(\mathrm{H}_{2} \mathrm{CO}_{3}\right)$ to lower the $\mathrm{pH}$ or to inhibit the growth of bacteria $[18,30,31]$. Combined with $\mathrm{HHP}$, this compressed $\mathrm{CO}_{2}$ dissolved in the liquid state could more easily penetrate the cells [30]. This not only triggered the higher expansion on the sudden release of high pressure to cause more serious cell disruption and membrane damage (morphology damages) but also resulted in the decrease of intracellular $\mathrm{pH}$ and disturbance of homeostasis, as well as the extraction of microbial constituents (intracellular structure damage) [32,33]. Also, the major sites of action for $\mathrm{CO}_{2}$ and $\mathrm{HHP}$ treatment were in the cell membrane, and highly-compressed $\mathrm{CO}_{2}$ could more easily dissolve in and distort these regions [34]. This might explain why $\mathrm{CO}_{2}$-packed samples by high pressure obtained higher reductions in microbial counts and heavier destruction of the morphology and cellular structures than those treated with HHP alone. However, for $\mathrm{N}_{2}$-packed E. coli cells, the intracellular structure was seriously damaged because it is highly hydrophobic and could dissolve in and distort the cellular core to upset hydrophobic interactions in the proteins [15], but their morphology remained unchanged during HHP treatment. This may explain why the reduction in the $\mathrm{N}_{2}$-packed E. coli cells was less than that of the $\mathrm{CO}_{2}$-packed cells.

Thus, it seems that HHP treatment combined with $\mathrm{CO}_{2}$ might inactivate microorganisms by destroying the cellular structure, accompanied by cell rupture. In contrast, the $\mathrm{N}_{2}$-packed cells were possibly inactivated by HHP through destruction of the cellular structure. 


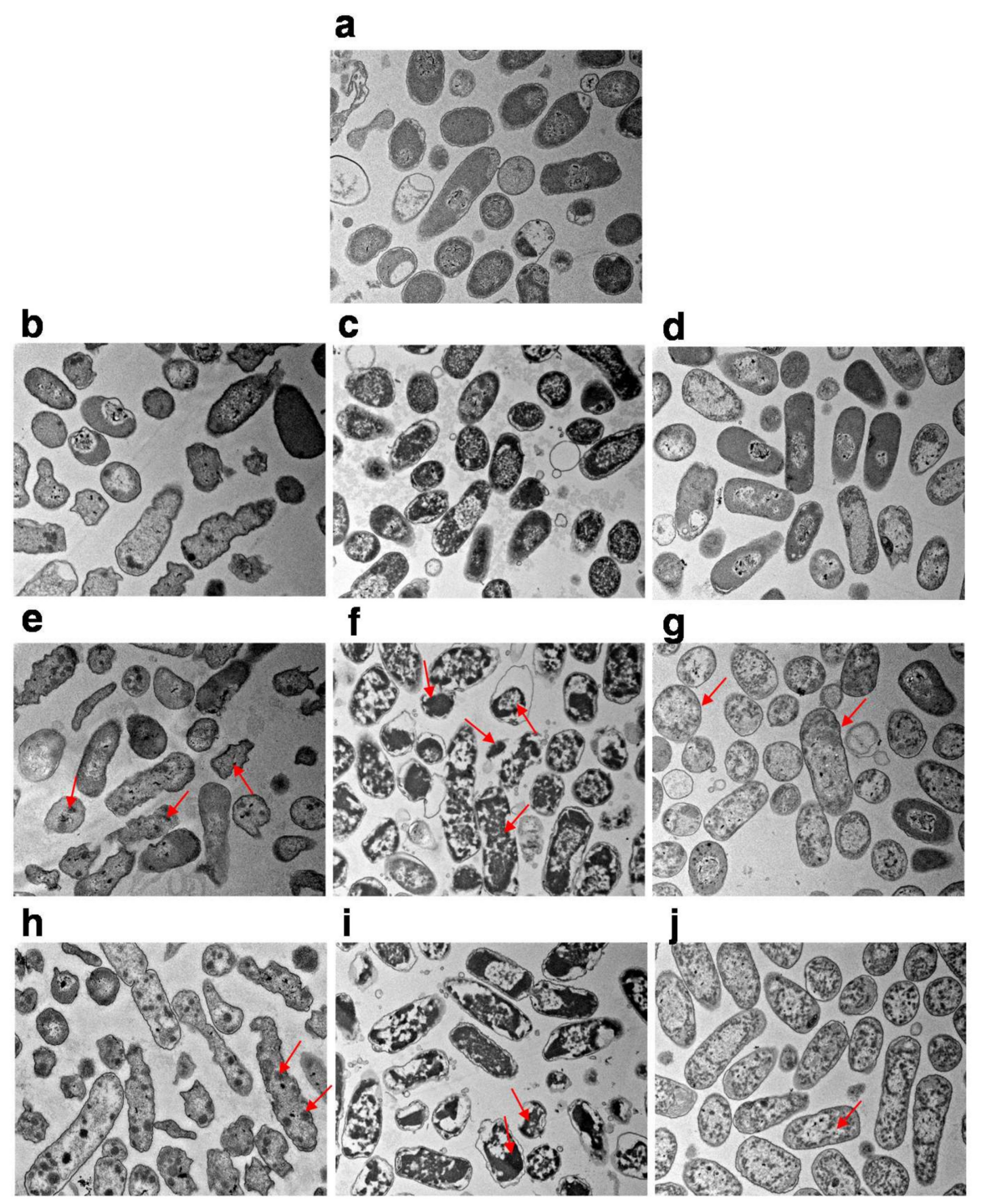

Figure 3. The transmission electron microscopy (TEM) images of differently packed E. coli before and after different pressure treatments. Untreated E. coli cells (a); vacuum-packed (b), $\mathrm{CO}_{2}$-packed (c), and $\mathrm{N}_{2}$-packed (d) E. coli cells after HHP treatment at $250 \mathrm{MPa}$ : Vacuum-packed (e), $\mathrm{CO}_{2}$-packed (f) and $\mathrm{N}_{2}$-packed (g) E. coli cells after HHP treatment at $350 \mathrm{MPa}$; Vacuum-packed (h), $\mathrm{CO}_{2}$-packed (i), and $\mathrm{N}_{2}$-packed (j) E. coli cells after HHP treatment at $450 \mathrm{MPa}$. Red arrows represent the remarkable phenotypes.

\subsection{Membrane Permeability of E. coli Cells}

For an analysis of the membrane damage in E. coli cells caused by high pressure, FCM combined with PI and SYTO9 was used. Comparing the profiles of the untreated and HHP treated cells, three groups were distinguished, and then regions were constructed to enumerate events within each group using the CellQuestTM program (Figure 4). Region 1 (R1) corresponded to the living cells with intact membranes (Figure 4). Region 2 (R2) was assigned as E. coli cells with unknown cultivability, which were in an intermediate state between dead cells and living cells, having damaged membrane and medium membrane permeability (Figure 4). Region 3 (R3) referred to the inactivated E. coli cells with fully damaged membranes, exhibiting high membrane permeability (Figure 4). After a 1-min pressure-holding time at $250 \mathrm{MPa}$, the majority of the $\mathrm{CO}_{2}$-packed E. coli cells was located in R3, which were higher than that of the $\mathrm{N}_{2}$-packed cells and vacuum-packed cells located in R3 (Figure 4c-e). For the pressure ranging from $350 \mathrm{MPa}$ to $450 \mathrm{MPa}$, although there were no significant differences in the proportion of cells in R3 among these treatments, the counts in the other two regions nearly 
disappeared for the combined treatment of $\mathrm{HHP}$ and $\mathrm{CO}_{2}$, while they still made up a small proportion in the $\mathrm{N}_{2}$-packed cells and vacuum-packed cells (Figure $4 \mathrm{f}-\mathrm{k}$ ). These results confirmed the synergistic effect of HHP treatment with $\mathrm{CO}_{2}$ on E. coli inactivation.
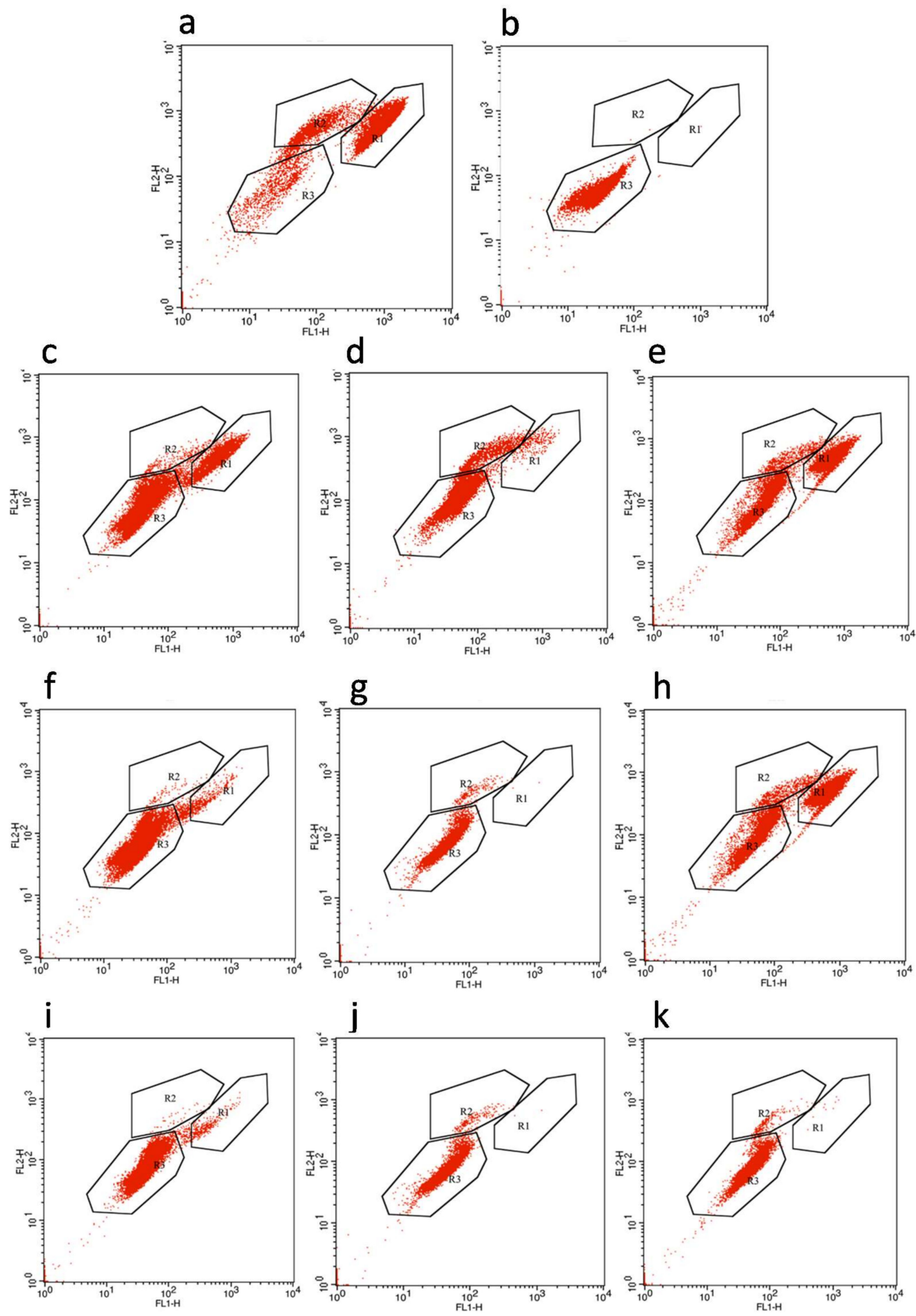

Figure 4. Flow cytometric analysis of E. coli differently packaged before and after different pressure treatments. Negative (a) and positive (b) E. coli cells; Vacuum-packed (c), $\mathrm{CO}_{2}$-packed (d), and $\mathrm{N}_{2}$-packed (e) E. coli cells after HHP treatment at $250 \mathrm{MPa}$ : Vacuum-packed (f), $\mathrm{CO}_{2}$-packed (g), and $\mathrm{N}_{2}$-packed (h) E. coli cells after HHP treatment at $350 \mathrm{MPa}$; Vacuum-packed E. coli cells (i), $\mathrm{CO}_{2}$-packed (j) and $\mathrm{N}_{2}$-packed (k) E. coli cells after HHP treatment at $450 \mathrm{MPa}$. 
Surprisingly, the vacuum-packed cells treated with high pressure transferred directly from R1 to R3 and did not go through R2 (Figure 4c,f,i). However, in the presence of gas, the HHP-treated cells transitioned from R1 to R2 and then to R3 as the pressure increased (Figure 4d,e,g,h,j,k). This indicated that the combined use of HHP and gases $\left(\mathrm{CO}_{2}\right.$ and $\left.\mathrm{N}_{2}\right)$ induced intermediate cells. This may be due to the mechanism of inactivation of E. coli cells by HHP combined with modified atmosphere packaging, which seems to be different from that of HHP alone.

Here, we show that the morphology of the $\mathrm{N}_{2}$-packed E. coli cells did not change at different pressures but its inner structure was seriously damaged. Also, although both the morphology and intracellular structure of the $\mathrm{CO}_{2}$-packed E. coli cells were strongly destroyed by the high pressure, this damage of the morphology may have been caused by damage to the inner structure. Furthermore, both the $\mathrm{CO}_{2}$-packed and $\mathrm{N}_{2}$-packed E. coli cells went through an intermediate phase during the high pressure. Based on our results, we propose the following model for the inactivation of cells by combing gas and high pressure. First, the combined use of HHP and gas facilitates the penetration of gas into the E. coli cells, which disturbs the intracellular reactions and causes clusters of proteins and the disruption of intracellular enzymes and organelles. Second, a sudden release in pressure ruptures the cells and damages their membranes, leading to the leakage of cytoplasm components. Therefore, this combined treatment might induce a series of cellular damage at first and then act on the membrane components and the extracellular morphology, unlike the independent HHP treatment that directly ruptures the cell membrane and then leads to the loss of internal substances, which would result in bacterial death [29].

\section{Conclusions}

In this study, the effect of the combination of HHP and gases to inactivate E. coli has been studied. The combined use of $\mathrm{HHP}$ and $\mathrm{CO}_{2}$ had a strong synergistic effect on the inactivation of E. coli cells, inducing serious destruction in the morphology and the membranes and cellular structure of the cells. In contrast, the combined use of $\mathrm{HHP}$ and $\mathrm{N}_{2}$ showed a similar inactivation effect to HHP alone and destroyed only the cellular structure and the membranes of the cells. Our results provide evidence that the combination of HHP and gases has a different inactivation mechanism than that of HHP treatment. In the presence of gas, the intracellular structure of the cells was damaged at first, and then the membrane and extracellular morphology were destroyed because of the solution of gas and the release of high pressure.

Author Contributions: For research articles with several authors, a short paragraph specifying their individual contributions must be provided. The following statements should be used conceptualization, B.Z., L.Z. and Y.Z.; methodology, B.Z., L.Z. and P.D.; software, P.D. and X.W.; validation, X.W., B.Z. and X.H.; formal analysis, X.W.; investigation, B.Z., L.Z., X.W., P.D., X.H. and Y.Z.; resources, X.H. and Y.Z.; data curation, B.Z.; writing-original draft preparation, B.Z. and Y.Z.; Writing-Review and editing, B.Z., X.W. and Y.Z.

Funding: This work was supported by the National Key Research and Development Plan during the 13th five-year plan period (No. 2017YFD0400504), as well as the key Program of National Natural Science Foundation of China (No. 31530058).

Conflicts of Interest: The authors declare no conflict of interest.

\section{References}

1. Ortega-Rivas, E.; Salmeron-Ochoa, I. Nonthermal Food Processing Alternatives and Their Effects on Taste and Flavor Compounds of Beverages. Crit. Rev. Food Sci. 2014, 54, 190-207. [CrossRef] [PubMed]

2. Fonberg-Broczek, M.; Windyga, B.; Szczawinski, J.; Szczawinska, M.; Pietrzak, D.; Prestamo, G. High pressure processing for food safety. Acta. Biochim. Pol. 2005, 52, 721-724.

3. Van Impe, J.; Smet, C.; Tiwari, B.; Greiner, R.; Ojha, S.; Stulic, V.; Vukusic, T.; Jambrak, A.R. State of the art of nonthermal and thermal processing for inactivation of micro-organisms. J. Appl. Microbiol. 2018, 125, 16-35. [CrossRef] [PubMed]

4. Lou, F.F.; Neetoo, H.; Chen, H.Q.; Li, J.R. High Hydrostatic Pressure Processing: A Promising Nonthermal Technology to Inactivate Viruses in High-Risk Foods. Annu. Rev. Food Sci. Technol. 2015, 6, 389-409. [CrossRef] [PubMed] 
5. Huang, H.W.; Lung, H.M.; Yang, B.B.; Wang, C.Y. Responses of microorganisms to high hydrostatic pressure processing. Food Control. 2014, 40, 250-259. [CrossRef]

6. Cruz-Romero, M.; Kelly, A.L.; Kerry, J.P. Influence of packaging strategy on microbiological and biochemical changes in high-pressure-treated oysters (Crassostrea gigas). J. Sci. Food Agric. 2008, 88, 2713-2723. [CrossRef]

7. Black, E.P.; Setlow, P.; Hocking, A.D.; Stewart, C.M.; Kelly, A.L.; Hoover, D.G. Response of spores to high-pressure processing. Compr. Rev. Food Sci. Food Saf. 2007, 6, 103-119. [CrossRef]

8. Sarker, M.R.; Akhtar, S.; Torres, J.A.; Paredes-Sabja, D. High hydrostatic pressure-induced inactivation of bacterial spores. Crit. Rev. Food Sci. 2015, 41, 18-26. [CrossRef] [PubMed]

9. San Martin, M.F.; Barbosa-Canovas, G.V.; Swanson, B.G. Food processing by high hydrostatic pressure. Crit. Rev. Food Sci. 2002, 42, 627-645. [CrossRef]

10. Queiros, R.P.; Gouveia, S.; Saraiva, J.A.; Lopes-da-Silva, J.A. Impact of $\mathrm{pH}$ on the high-pressure inactivation of microbial transglutaminase. Food Res. Int. 2019, 115, 73-82. [CrossRef]

11. Pyatkovskyy, T.I.; Shynkaryk, M.V.; Mohamed, H.M.; Yousef, A.E.; Sastry, S.K. Effects of combined high pressure (HPP), pulsed electric field (PEF) and sonication treatments on inactivation of Listeria innocua. J. Food Eng. 2018, 233, 49-56. [CrossRef]

12. Ross, A.I.V.; Griffiths, M.W.; Mittal, G.S.; Deeth, H.C. Combining nonthermal technologies to control foodborne microorganisms. Int J. Food Microbiol. 2003, 89, 125-138. [CrossRef]

13. Roberts, C.M.; Hoover, D.G. Sensitivity of Bacillus coagulans spores to combinations of high hydrostatic pressure, heat, acidity and nisin. J. Appl. Bacteriol. 1996, 81, 363-368.

14. Rodriguez-Calleja, J.M.; Cruz-Romero, M.C.; O'Sullivan, M.G.; Garcia-Lopez, M.L.; Kerry, J.P. High-pressure-based hurdle strategy to extend the shelf-life of fresh chicken breast fillets. Food Control. 2012, 25, 516-524. [CrossRef]

15. Arao, T.; Hara, Y.; Suzuki, Y.; Tamura, K. Effect of high-pressure gas on yeast growth. Biosci. Biotech. Bioch. 2005, 69, 1365-1371. [CrossRef] [PubMed]

16. Debs-Louka, E.; Louka, N.; Abraham, G.; Chabot, V.; Allaf, K. Effect of compressed carbon dioxide on microbial cell viability. Appl. Environ. Microbiol. 1999, 65, 626-631. [PubMed]

17. Amanatidou, A.; Slump, R.A.; Gorris, L.G.M.; Smid, E.J. High oxygen and high carbon dioxide modified atmospheres for shelf-life extension of minimally processed carrots. J. Food Sci. 2000, 65, 61-66. [CrossRef]

18. Garcia-Gonzalez, L.; Geeraerd, A.H.; Spilimbergo, S.; Elst, K.; Van Ginneken, L.; Debevere, J.; Van Impe, J.F.; Devlieghere, F. High pressure carbon dioxide inactivation of microorganisms in foods: The past, the present and the future. Int. J. Food Microbiol. 2007, 117, 1-28. [CrossRef]

19. Lerasle, M.; Federighi, M.; Simonin, H.; Anthoine, V.; Reee, S.; Cheret, R.; Guillou, S. Combined use of modified atmosphere packaging and high pressure to extend the shelf-life of raw poultry sausage. Innov. Food Sci. Emerg. Technol. 2014, 23, 54-60. [CrossRef]

20. Al-Nehlawi, A.; Guri, S.; Guamis, B.; Saldo, J. Synergistic effect of carbon dioxide atmospheres and high hydrostatic pressure to reduce spoilage bacteria on poultry sausages. LWT-Food Sci. Technol. 2014, 58, 404-411. [CrossRef]

21. Wang, L.; Pan, J.A.; Xie, H.M.; Yang, Y.; Lin, C.M. Inactivation of Staphylococcus aureus and Escherichia coli by the synergistic action of high hydrostatic pressure and dissolved $\mathrm{CO}_{2}$. Int. J. Food Microbiol. 2010, 144, 118-125. [CrossRef] [PubMed]

22. Deng, K.; Serment-Moreno, V.; Welti-Chanes, J.; Paredes-Sabja, D.; Fuentes, C.; Wu, X.; Torres, J.A. Inactivation model and risk-analysis design for apple juice processing by high-pressure $\mathrm{CO}_{2}$. J. Food Sci. Technol. 2018, 55, 258-264. [CrossRef] [PubMed]

23. Li, H.; Xu, Z.Z.; Zhao, F.; Wang, Y.T.; Liao, X.J. Synergetic effects of high-pressure carbon dioxide and nisin on the inactivation of Escherichia coli and Staphylococcus aureus. Innov. Food Sci. Emerg. Technol. 2016, 33, 180-186. [CrossRef]

24. Liao, H.M.; Zhang, F.S.; Liao, X.J.; Hu, X.S.; Chen, Y.; Deng, L. Analysis of Escherichia coli cell damage induced by HPCD using microscopies and fluorescent staining. Int. J. Food Microbiol. 2010, 144, 169-176. [CrossRef] [PubMed]

25. Liao, H.M.; Zhang, F.S.; Hu, X.S.; Liao, X.J. Effects of high-pressure carbon dioxide on proteins and DNA in Escherichia coli. Microbiology-Sgm 2011, 157, 709-720. [CrossRef] [PubMed] 
26. Amor, K.B.; Breeuwer, P.; Verbaarschot, P.; Rombouts, F.M.; Akkermans, A.D.; De Vos, W.M.; Abee, T. Multiparametric flow cytometry and cell sorting for the assessment of viable, injured, and dead bifidobacterium cells during bile salt stress. Appl. Environ. Microbiol. 2002, 68, 5209-5216. [CrossRef]

27. Erkmen, O.; Dogan, C. Kinetic analysis of Escherichia coli inactivation by high hydrostatic pressure in broth and foods. Food Microbiol. 2004, 21, 181-185. [CrossRef]

28. Chen, H.Q.; Hoover, D.G. Pressure inactivation kinetics of Yersinia enterocolitica ATCC 35669. Int. J. Food Microbiol. 2003, 87, 161-171. [CrossRef]

29. Abe, F. Exploration of the effects of high hydrostatic pressure on microbial growth, physiology and survival: Perspectives from piezophysiology. Biosci. Biotech. Bioch. 2007, 71, 2347-2357. [CrossRef]

30. Lo, R.; Xue, T.; Weeks, M.; Turner, M.S.; Bansal, N. Inhibition of bacterial growth in sweet cheese whey by carbon dioxide as determined by culture-independent community profiling. Int. J. Food Microbiol. 2016, 217, 20-28. [CrossRef]

31. Jakobsen, M.; Bertelsen, G. Solubility of carbon dioxide in fat and muscle tissue. J. Muscle Food 2006, 17, 9-19. [CrossRef]

32. Zhao, F.; Wang, Y.T.; An, H.R.; Hao, Y.L.; Hu, X.S.; Liao, X.J. New Insights into the Formation of Viable but Nonculturable Escherichia coli O157:H7 Induced by High-Pressure $\mathrm{CO}_{2}$. Mbio 2016, 7, e00961-16. [CrossRef] [PubMed]

33. Provincial, L.; Guillen, E.; Alonso, V.; Gil, M.; Roncales, P.; Beltran, J.A. Survival of Vibrio parahaemolyticus and Aeromonas hydrophila in sea bream (Sparus aurata) fillets packaged under enriched $\mathrm{CO}_{2}$ modified atmospheres. Int. J. Food Microbiol. 2013, 166, 141-147. [CrossRef] [PubMed]

34. Hong, S.I.; Pyun, Y.R. Membrane damage and enzyme inactivation of Lactobacillus plantarum by high pressure CO2 treatment. Int. J. Food Microbiol. 2001, 63, 19-28. [CrossRef]

(C) 2019 by the authors. Licensee MDPI, Basel, Switzerland. This article is an open access article distributed under the terms and conditions of the Creative Commons Attribution (CC BY) license (http://creativecommons.org/licenses/by/4.0/). 